\title{
Heat-Resistant Properties of $\alpha$-Chymotrypsin Adsorbed onto Biomass Charcoal Powder
}

\author{
Hidetaka Noritomi ${ }^{*}$, Shunichi Kurihara', Nobuyuki Endo ${ }^{2}$, Satoru Kato ${ }^{1}$ \\ ${ }^{1}$ Department of Applied Chemistry, Tokyo Metropolitan University, Tokyo, Japan \\ ${ }^{2}$ EEN Co., Ltd., Tokyo, Japan \\ Email: ${ }^{*}$ noritomi@tmu.ac.jp
}

Received 19 June 2014; revised 6 July 2014; accepted 16 July 2014

Copyright (C) 2014 by authors and Scientific Research Publishing Inc.

This work is licensed under the Creative Commons Attribution International License (CC BY). http://creativecommons.org/licenses/by/4.0/

c) (i) Open Access

\begin{abstract}
Biomass charcoal powder (BCP) was used as a carrier for immobilization of $\alpha$-chymotrypsin through adsorption. BCP was derived from plant biomass wastes such as dumped bamboos by oxygen-free pyrolysis at low temperatures and grinding with a jet mill. The activity of adsorbed $\alpha$-chymotrypsin was strongly dependent upon the kind of BCP. The thermal denaturation curve of adsorbed $\alpha$-chymotrypsin was shifted to high temperature, compared to that of free one. When $\alpha$-chymotrypsin adsorbed onto BCP of bamboos was incubated at $45^{\circ} \mathrm{C}$, the half-life of adsorbed $\alpha$-chymotrypsin was 2.6 times greater than that of free one. After incubation at $45^{\circ} \mathrm{C}$, the remaining activity of adsorbed $\alpha$-chymotrypsin markedly depended on the kind of BCP.
\end{abstract}

\section{Keywords}

Adsorption, Biomass Charcoal Powder, $\alpha$-Chymotrypsin, Activity, Thermal Stability

\section{Introduction}

Adsorption of enzymes onto various water-insoluble carriers has attracted continuous attention in the fields of biotechnology, fine chemistry, pharmacy, and biosensor, since the immobilization of enzymes by adsorption has been considered as the simplest and most economical method [1] [2]. Furthermore, since the performances of adsorbed enzymes such as activity, specificity, and stability largely depend upon the physical and chemical surface properties of carriers, it is possible to derive the desired performances of enzymes by selecting a suitable carrier [3].

\footnotetext{
${ }^{*}$ Corresponding author.
}

How to cite this paper: Noritomi, H., Kurihara, S., Endo, N. and Kato, S. (2014) Heat-Resistant Properties of $\alpha$-Chymotrypsin Adsorbed onto Biomass Charcoal Powder. Journal of Biomaterials and Nanobiotechnology, 5, 179-185. 
On the other hand, technologies for producing useful products such as fuels and materials from biomass waste have been developed in order to establish recycling society. Plant biomass charcoal prepared from plant biomass wastes has been widely studied as renewable resources. Plant biomass charcoal has been applied to soil amendments, adsorbents, humidity control materials, materials for wastewater treatment, and catalysts [4]-[9]. However, plant biomass wastes have not sufficiently been recycled yet, compared to other wastes, although an enormous amount of plant biomass wastes has been discharged in the world. Moreover, the development in the high value-added function of plant biomass charcoal has been desired.

In order to assess the property of plant biomass charcoal as a biomaterial, we have so far investigated the interaction between a protein and plant biomass charcoal derived from dumped adzuki beans and so on, when hen egg white lysozyme (HEWL) was used as a model protein, and have found out that plant biomass charcoal effectively adsorbs HEWL, and HEWL adsorbed onto plant biomass charcoal exhibits the enhanced storage stability at low temperatures and the excellent thermal stability at high temperatures, compared to those of free HEWL [10]-[12]. In addition, we have reported that plant biomass charcoal can sufficiently adsorbs $\alpha$-chymotrypsin [13].

In the present work, in order to assess the generality on the stabilization effect of plant biomass charcoal on proteins, we employed bovine pancreas $\alpha$-chymotrypsin as a model protein, since it is well investigated regarding its structure, functions, and properties [14]. The finely grinded biomass charcoal powder was derived from plant biomass wastes such as dumped bamboos by oxygen-free pyrolysis at low temperatures and grinding with a jet mill.

\section{Materials and Methods}

\subsection{Materials}

$\alpha$-Chymotrypsin (EC 3.4.21.1 from bovine pancreas) (Type II, 52 units/mg solid) was purchased from Sigma-Aldrich Co. (St. Louis, USA). p-Nitrophenyl acetate was obtained from Wako Pure Chemical Industries, Ltd. (Osaka, Japan).

\subsection{Preparation and SEM Image of Biomass Charcoal Powder}

Under nitrogen atmosphere, dumped bamboos were dried at $180^{\circ} \mathrm{C}$ for $2 \mathrm{hr}$, were pyrolyzed at $450^{\circ} \mathrm{C}$ for $2 \mathrm{hr}$, were carbonized at $350^{\circ} \mathrm{C}$ for $3 \mathrm{hr}$, and then were cooled at $100^{\circ} \mathrm{C}$ for $1 \mathrm{hr}$ by pyrolyzer (EE21 Pyrolyzer, EEN Co. Ltd., Japan), as shown in Figure 1. Biomass charcoal powder (BCP) was obtained by grinding the resultant biomass charcoal (BC) with jet mill (100AS, Fuji Sangyo Co. Ltd., Japan). BCP of waste adzuki beans or woods was prepared by the same method.

The SEM micrograph was obtained using a scanning electron microscope (JSM-7500FA, JEOL, Japan) operating at $15 \mathrm{kV}$. The sample for SEM was prepared on a carbon tape without vapor deposition.

\subsection{Adsorption of $\alpha$-Chymotrypsin onto BCP}

As a typical procedure, $5 \mathrm{~mL}$ of $0.01 \mathrm{M}$ phosphate buffer solution at $\mathrm{pH} 7$ containing $300 \mu \mathrm{M} \alpha$-chymotrypsin and $3 \mathrm{~g} / \mathrm{L} \mathrm{BCP}$ was placed in a 10-mL test tube with a screw cup, and was incubated at $25^{\circ} \mathrm{C}$ and $120 \mathrm{rpm}$ for $24 \mathrm{~h}$. After adsorption, the mixture was filtrated with a membrane filter (pore size: $0.1 \mu \mathrm{m}$, Millipore Co. Ltd.) to col-
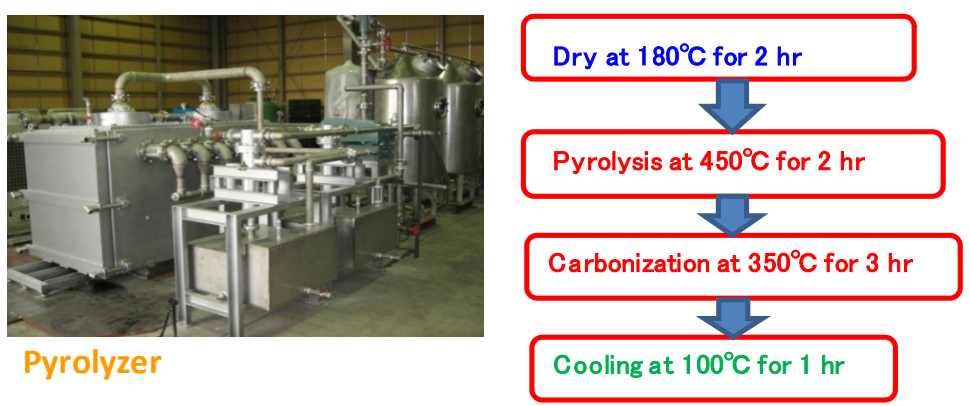

Figure 1. Scheme of preparation of biomass charcoal. 
lect $\alpha$-chymotrypsin adsorbed onto BCP. The amount of $\alpha$-chymotrypsin adsorbed onto BCP was calculated by subtracting the amount of $\alpha$-chymotrypsin included in the supernatant liquid after adsorption from the amount of $\alpha$-chymotrypsin in the aqueous solution before adsorption. The amount of $\alpha$-chymotrypsin was measured at 280 $\mathrm{nm}$ by UV/vis spectrophotometer (UV-1800, Shimadzu Co. Ltd.).

\subsection{Measurement of Activity of Free and Adsorbed $\alpha$-Chymotrypsin}

$\alpha$-Chymotrypsin activity was determined using $p$-nitrophenyl acetate as a substrate [15]. Four $\mathrm{mL}$ of $0.01 \mathrm{M}$ phosphate buffer solution at $\mathrm{pH} 7.5$ containing free or adsorbed $\alpha$-chymotrypsin $(29.5 \mu \mathrm{M})$ was added to $16 \mathrm{~mL}$ of $0.01 \mathrm{M}$ phosphate buffer solution at $\mathrm{pH} 7.5$ containing $750 \mu \mathrm{M}$ p-nitrophenyl acetate, and the mixture was incubated at $25^{\circ} \mathrm{C}$ and $120 \mathrm{rpm}$. The absorbance of the mixture was periodically measured at $400 \mathrm{~nm}$ by UV/vis spectrophotometer (UV-1800, Shimadzu Co. Ltd.).

\subsection{Effect of Temperature on Stability of Free and Adsorbed $\alpha$-Chymotrypsin}

In order to assess the thermal stability of free and adsorbed $\alpha$-chymotrypsin, the activity of free or adsorbed $\alpha$-chymotrypsin was measured after free or adsorbed $\alpha$-chymotrypsin was stored in $0.01 \mathrm{M}$ phosphate buffer solution at $\mathrm{pH} 7.5$ and $45^{\circ} \mathrm{C}$ for $10 \mathrm{~min}$, and then was cooled at $25^{\circ} \mathrm{C}$ for $60 \mathrm{~min}$. The residual activity was obtained by Equation (1).

$$
\text { Remaining activity }(\%)=\frac{\text { Activity after heat treatment }}{\text { Activity before heat treatment }} \times 100
$$

\section{Results and Discussion}

\subsection{Characterization of $\mathrm{BCP}$}

The present method for preparing BCP is an environmentally benign process, since plant biomass wastes are not burned in the process of pyrolysis at low temperatures. As seen in Figure 2, the morphology in BC of bamboos was kept, similar to that in native bamboos. Additionally, functional groups containing oxygen atoms are formed by thermal decomposition of cellulose and hemicelluloses at low temperatures, and are useful for the adsorption of proteins [16].

Figure 3 shows the scanning electron micrograph of BCP of bamboos. As seen in the figure, any distinguishing roughness was not observed on the surface of BCP of bamboos. In our previous work [10], the mean diameter of BCP of bamboos was $7 \mu \mathrm{m}$. Specific surface area of BCP of bamboos was $294 \mathrm{~m}^{2} / \mathrm{g}$ [13]. The pore
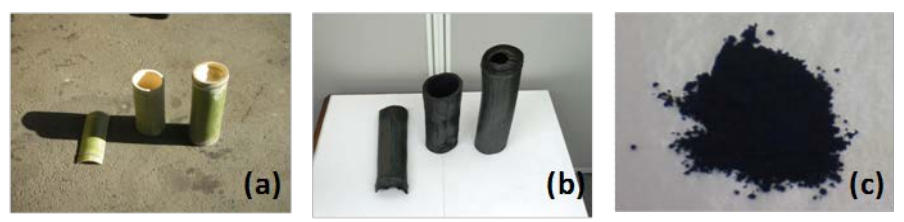

Figure 2. Photographs of BCP of bamboos: (a) raw bamboos; (b) biomass charcoal (BC) of bamboos after pyrolysis; (c) biomass charcoal powder (BCP) of bamboos obtained after grinding.

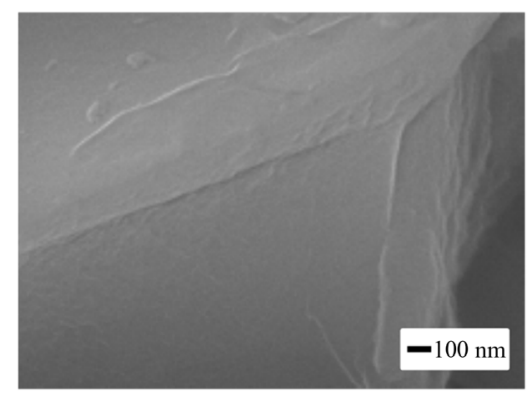

Figure 3. SEM image of BCP of bamboos. 
diameter peak was less than $2.6 \mathrm{~nm}$ [13]. The $\zeta$ potential of BCP of bamboos was $-53.5 \mathrm{mV}$ at solution $\mathrm{pH} 7$ [10]. Moreover, from the results of ${ }^{13} \mathrm{C}-\mathrm{NMR}$ and X-ray photoelectron spectroscopy (XPS), acidic functional groups such as phenols, carbonyl groups, and carboxyl groups were detected in BCP [10].

\subsection{Activity of $\alpha$-Chymotrypsin Adsorbed onto Different Kinds of Biomass Charcoal Powder}

The surface chemical and pore properties of BCP are strongly dependent upon a kind of plant biomass wastes [10] [13]. In order to assess the influence of the kind of BCP on the activity of $\alpha$-chymotrypsin adsorbed onto BCP, the activities of $\alpha$-chymotrypsin adsorbed onto BCP prepared from different kinds of plant biomass wastes were investigated. As seen in Figure 4, the activity of adsorbed $\alpha$-chymotrypsin was smaller than that of free one. Moreover, the activity of adsorbed $\alpha$-chymotrypsin markedly depended upon the kind of BCP, and the activity of $\alpha$-chymotrypsin adsorbed onto BCP of bamboos was the highest value. The activity of $\alpha$-chymotrypsin adsorbed onto BCP of bamboos was $1.48 \mu \mathrm{mol} / \mathrm{min} \cdot \mathrm{g}$ of enzyme, while that of free $\alpha$-chymotrypsin was 8.67 $\mu \mathrm{mol} / \mathrm{min} \cdot \mathrm{g}$ of enzyme. Therefore, the effectiveness factor, which was defined as the ratio of the activity of $\alpha$-chymotrypsin adsorbed onto BCP to that of free one, exhibited 0.17 . On the other hand, from the results of ${ }^{13} \mathrm{C}-\mathrm{NMR}$ and XPS, acidic functional groups such as phenols, carbonyl groups, and carboxyl groups are detected on the surface of BCP [10]. Moreover, since the amount of $\alpha$-chymotrypsin adsorbed onto BCP is strongly influenced by the solution $\mathrm{pH}$ and the salt concentration, electrostatic interactions and hydrogen bonds via functional groups largely contribute to the adsorption of enzymes onto BCP [13]. Thus, it is suggested that the flexibility of enzymes might be limited by the adsorption. Additionally, it is possible that enzymes are partially denatured, and the active site of enzymes is shielded due to the undesired orientation of enzyme molecules through the adsorption.

\subsection{Dependence of the Remaining Activity of $\alpha$-Chymotrypsin Adsorbed onto Bamboo Charcoal on Incubation Temperature}

Figure 5 shows the relationship between the incubation temperature and the remaining activity of free $\alpha$-chymotrypsin $(\alpha$-CT) or $\alpha$-chymotrypsin adsorbed onto BCP of bamboos after the incubation time for 10 min. As seen in the figure, the dependence of the remaining activity on the temperature exhibited the sigmoid curve. The remaining activity of $\alpha$-chymotrypsin adsorbed onto BCP of bamboos gradually dropped in the range from $35^{\circ} \mathrm{C}$ to $55^{\circ} \mathrm{C}$, and still exhibited $12 \%$ at $55^{\circ} \mathrm{C}$, which was four times larger than that of free enzyme, although the remaining activity of free $\alpha$-chymotrypsin dramatically decreased with an increase in temperature in the range from $35^{\circ} \mathrm{C}$ to $55^{\circ} \mathrm{C}$. Additionally, the transition temperature of $\alpha$-chymotrypsin adsorbed onto BCP of bamboos was around $46^{\circ} \mathrm{C}$, whereas that of free $\alpha$-chymotrypsin was around $41^{\circ} \mathrm{C}$, similar to that measured by fluorescence analysis [17]. These results indicated that adsorbing $\alpha$-chymotrypsin onto BCP of bamboos effectively enhanced the thermal stability of $\alpha$-chymotrypsin. Specifically, the difference of the remaining activity between adsorbed enzyme and free enzyme was observed around $50^{\circ} \mathrm{C}$, where is the optimum temperature of $\alpha$-chymotrypsin [14]. In addition to the maintenance of enzyme structures due to the adsorption of enzyme molecules, it

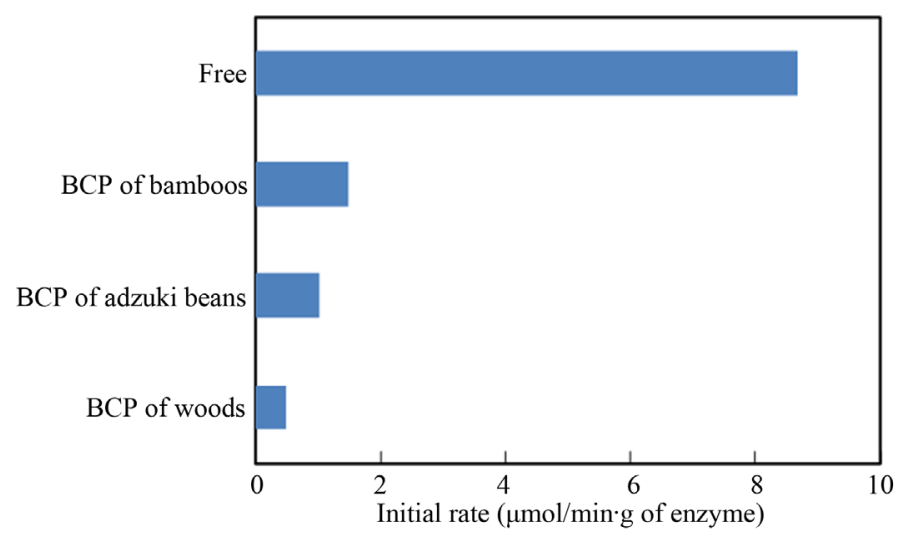

Figure 4. Activities of $\alpha$-chymotrypsin adsorbed onto different BCP. 


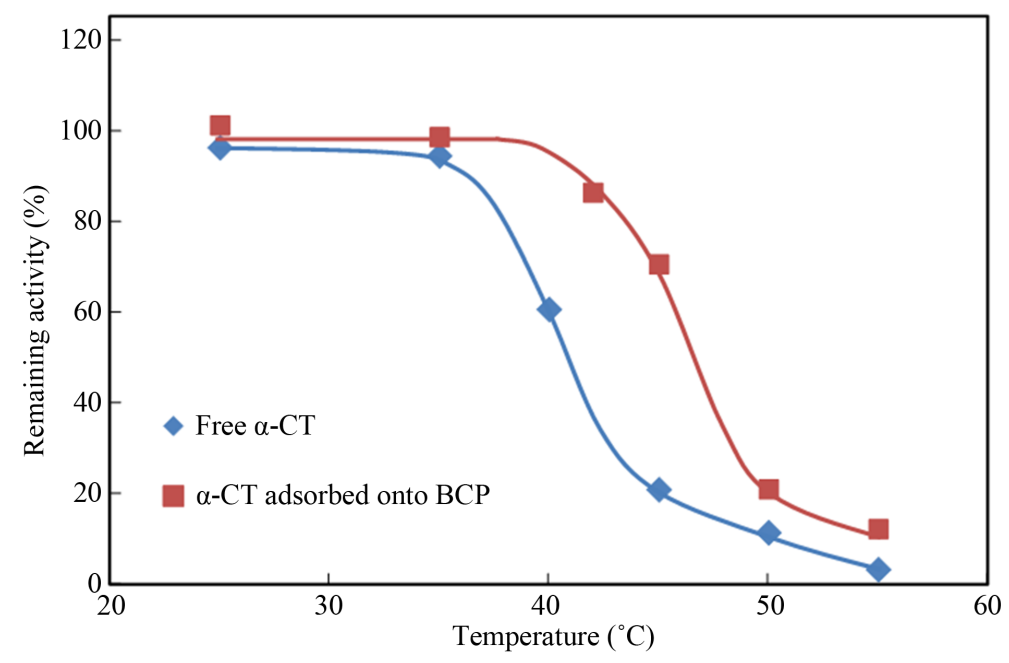

Figure 5. Thermal denaturation curves of free $\alpha$-chymotrypsin and $\alpha$-chymotrypsin adsorbed onto BCP of bamboos. The aqueous solution of free $\alpha$-chymotrypsin or $\alpha$-chymotrypsin adsorbed onto BCP of bamboos was incubated at requisite temperature for $10 \mathrm{~min}$.

was suggested that the autolysis of enzymes was inhibited by adsorbing enzyme molecules onto BCP of bamboos, while free enzyme was gradually denatured in water by autolysis.

\subsection{Time Dependent Inactivation of $\alpha$-Chymotrypsin}

In general, the activity of enzymes gradually decreases with an increase in incubation time. Figure 6 shows the time course of remaining activities of free $\alpha$-chymotrypsin and $\alpha$-chymotrypsin adsorbed onto BCP of bamboos at $\mathrm{pH} 7.5$ and $45^{\circ} \mathrm{C}$. Free $\alpha$-chymotrypsin solution was transparent during the incubation. On the other hand, any cohesion of adsorbed enzymes was not observed during the incubation. Thus, the intermolecular aggregation among unfolded proteins was not observed at the present enzyme concentration. The figure revealed that the adsorbed enzyme retained relatively high catalytic activity. In the figure, the relationship of the remaining activities of free and adsorbed enzymes with incubation time can be correlated by first-order kinetics. As shown in Table 1, the half-life of adsorbed enzymes was 2.6 times longer than that of free enzymes. Thus, the robust stability of enzymes was obtained by adsorbing enzyme molecules onto BCP.

\subsection{Remaining Activity of $\alpha$-Chymotrypsin Adsorbed onto Different Kinds of Biomass Charcoal Powder after Heat Treatment}

In order to extend our study, the remaining activities of $\alpha$-chymotrypsin adsorbed onto BCP prepared from different kinds of plant biomass wastes after the incubation at $45^{\circ} \mathrm{C}$ for $10 \mathrm{~min}$ were investigated. The stability of $\alpha$-chymotrypsin was sufficiently enhanced by adsorbing $\alpha$-chymotrypsin onto BCP, as shown in Figure 7, compared to that of free $\alpha$-chymotrypsin. The sequence of the remaining activity of BCP-adsorbed $\alpha$-chymotrypsin went as follows: BCP of bamboos > BCP of woods > BCP of adzuki beans. On the other hand, the sequence of the remaining activity of BCP-adsorbed HEWL went as follows: BCP of adzuki beans $>$ BCP of woods $>$ BCP of bamboos in our previous work [12]. These results indicate that a suitable kind of BCP to one protein depends upon a kind of protein.

\section{Conclusion}

We have demonstrated that BCP is useful to protein carrier from the standpoint of the activity and stability of $\alpha$ chymotrypsin. The kind of BCP affected the activity and stability of adsorbed $\alpha$-chymotrypsin. Especially, $\alpha$ chymotrypsin adsorbed onto BCP of bamboos exhibited sufficient activity and stability. On the other hand, HEWL adsorbed onto BCP of adzuki beans showed excellent storage and thermal stability [11] [12]. Therefore, a suitable kind of BCP to one protein is dependent upon a kind of protein. There are various kinds of plant bio- 


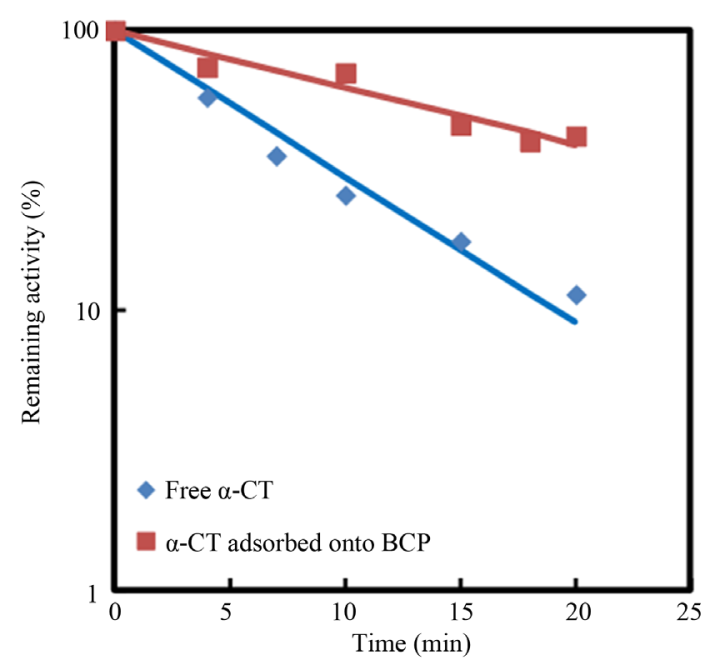

Figure 6. Time course of remaining activities of free $\alpha$-chymotrypsin and $\alpha$-chymotrypsin adsorbed onto BCP of bamboos through the heat treatment at $45^{\circ} \mathrm{C}$.

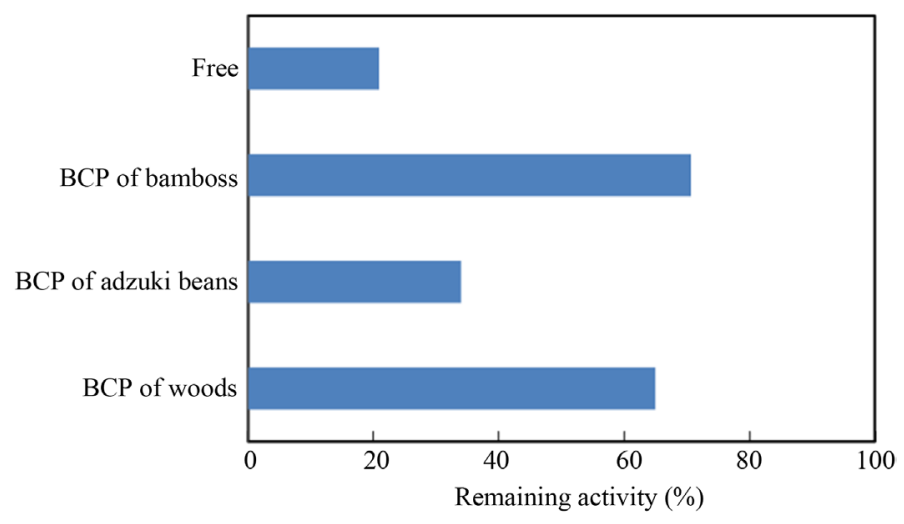

Figure 7. Effect of kind of BCP on remaining activity of $\alpha$-chymotrypsin adsorbed onto BCP after heat treatment at $45^{\circ} \mathrm{C}$ for $10 \mathrm{~min}$.

Table 1. Rate constants and half-lives of inactivation of $\alpha$-chymotrypsin at $45^{\circ} \mathrm{C}$.

\begin{tabular}{ccc}
\hline Samples & Rate constant $\left(\mathrm{min}^{-1}\right)$ & Half life (min) \\
\hline Free $\alpha$-chymotrypsin & 0.12 & 5.8 \\
BCP-adsorbed $\alpha$-chymotrypsin & 0.047 & 15 \\
\hline
\end{tabular}

mass waste on earth. Accordingly, the enhancement in the performance of proteins shown by adsorbing proteins onto BCP would be encouraging for its choice in application such as a biomaterial.

\section{Acknowledgements}

This work was supported by a Grant-in-Aid for Scientific Research from Japan Society for the Promotion of Science (C) (No. 24561013).

\section{References}

[1] Elnashar, M.M.M. (2010) Review Article: Immobilized Molecules Using Biomaterials and Nanobiotechnology. Journal of Biomaterials and Nanobiotechnology, 1, 61-77. http://dx.doi.org/10.4236/jbnb.2010.11008

[2] Mateo, C., Palomo, J.M., Fernandez-Lorente, G., Guisan, J.M. and Fernandez-Lorente, R. (2007) Improvement of En- 
zyme Activity, Stability and Selectivity via Immobilization Techniques. Enzyme and Microbial Technology, 40, 14511463. http://dx.doi.org/10.1016/j.enzmictec.2007.01.018

[3] Buchholz, K., Kasche, V. and Bornscheuer, U.T. (2005) Biocatalysts and Enzyme Technology. Wiley-VCH, Weinheim.

[4] Cross, A. and Sohi, S.P. (2011) The Priming Potential of Biochar Products in Relation to Labile Carbon Contents and Soil Organic Matter Status. Soil Biology \& Biochemistry, 43, 2127-2134. http://dx.doi.org/10.1016/j.soilbio.2011.06.016

[5] Pulido, L.L., Hata, T., Imamura, Y., Ishihara, S. and Kajimoto, T. (1998) Removal of Mercury and Other Metals by Carbonized Wood Powder from Aqueous Solutions of Their Salts. Journal of Wood Science, 44, 237-243. http://dx.doi.org/10.1007/BF00521970

[6] Abe, I., Hitomi, M., Ikuta, N., Kawafune, I., Noda, K. and Kera, Y. (1995) Humidity-Control Capacity of Microporous Carbon. Seikatsu Eisei, 39, 333-336.

[7] Khalfaoui, B., Meniai, A.H. and Borja, R. (1995) Removal of Copper from Industrial Wastewater by Raw Charcoal Obtained from Reeds. Journal of Chemical Technology and Biotechnology, 64, 153-156. http://dx.doi.org/10.1002/jctb.280640207

[8] Yatagai, M., Ito, R., Ohira, T. and Oba, K. (1995) Effect of Charcoal on Purification of Wastewater. Mokuzai Gakkaishi, 41, 425-432.

[9] Kominami, H., Sawai, K., Hitomi, M., Abe, I. and Kera, Y. (1994) Reduction of Nitrogen Monoxide by Charcoal. Nippon Kagakukaishi, 1994, 582-584. http://dx.doi.org/10.1246/nikkashi.1994.582

[10] Noritomi, H., Iwai, D., Kai, R., Tanaka, M. and Kato, S. (2013) Adsorption of Lysozyme on Biomass Charcoal Powder Prepared from Plant Biomass Wastes. Journal of Chemical Engineering of Japan, 46, 196-200. http://dx.doi.org/10.1252/jcej.12we182

[11] Noritomi, H., Ishiyama, R., Kai, R., Iwai, D., Tanaka, M. and Kato, S. (2012) Immobilization of Lysozyme on Biomass Charcoal Powder Derived from Plant Biomass Wastes. Journal of Biomaterials and Nanobiotechnology, 3, 446-451. http://dx.doi.org/10.4236/jbnb.2012.34045

[12] Noritomi, H., Kai, R., Iwai, D., Tanaka, H., Kamiya, R., Tanaka, M., Muneki, K. and Kato, S. (2011) Increase in Thermal Stability of Proteins Adsorbed on Biomass Charcoal Powder Prepared from Plant Biomass Wastes. Journal of Biomedical Science and Engineering, 4, 692-698. http://dx.doi.org/10.4236/jbise.2011.411086

[13] Noritomi, H., Hishinuma, K., Kurihara, S., Nishigami, J., Takemoto, T., Endo, N. and Kato, S. (2013) Adsorption of $\alpha$-Chymotrypsin on Plant Biomass Charcoal. Journal of Surface Engineered Materials and Advanced Technology, 3, 269-274. http://dx.doi.org/10.4236/jsemat.2013.34036

[14] Kumar, A. and Venkatesu, P. (2012) Overview of the Stability of $\alpha$-Chymotrypsin in Different Solvent Media. Chemical Reviews, 112, 4283-4307. http://dx.doi.org/10.1021/cr2003773

[15] Bender, M.L., Clement, G.E., Kézdy, F.J. and Heck, H.D’A. (1964) The Correlation of the pH (pD) Dependence and the Stepwise Methanism of $\alpha$-Chymotrypsin-Catalyzed Reactions. Journal of the American Chemical Society, 86, 3680-3690. http://dx.doi.org/10.1021/ja01072a017

[16] Nishimiya, K., Hata, T., Imamura, Y. and Ishihara, S. (1998) Analysis of Chemical Structure of Wood Charcoal by X-Ray Photoelectron Spectroscopy. Journal of Wood Science, 44, 56-61. http://dx.doi.org/10.1007/BF00521875

[17] Attri, P. and Venkatesu, P. (2013) Exploring the Thermal Stability of $\alpha$-Chymotrypsin in Protic Ionic Liquids. Process Biochemistry, 48, 462-470. http://dx.doi.org/10.1016/j.procbio.2013.02.006 
Scientific Research Publishing (SCIRP) is one of the largest Open Access journal publishers. It is currently publishing more than 200 open access, online, peer-reviewed journals covering a wide range of academic disciplines. SCIRP serves the worldwide academic communities and contributes to the progress and application of science with its publication.

Other selected journals from SCIRP are listed as below. Submit your manuscript to us via either submit@scirp.org or Online Submission Portal.
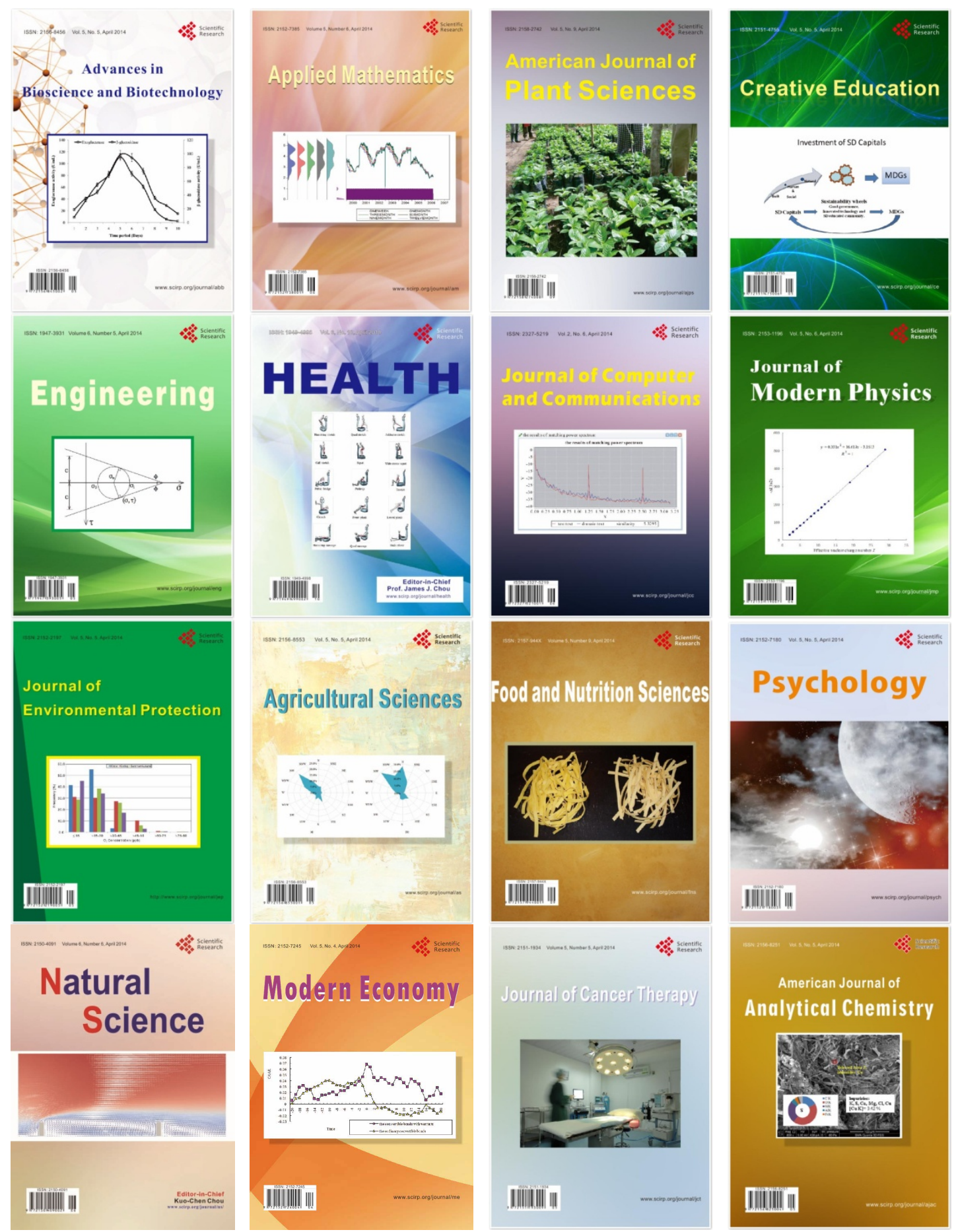